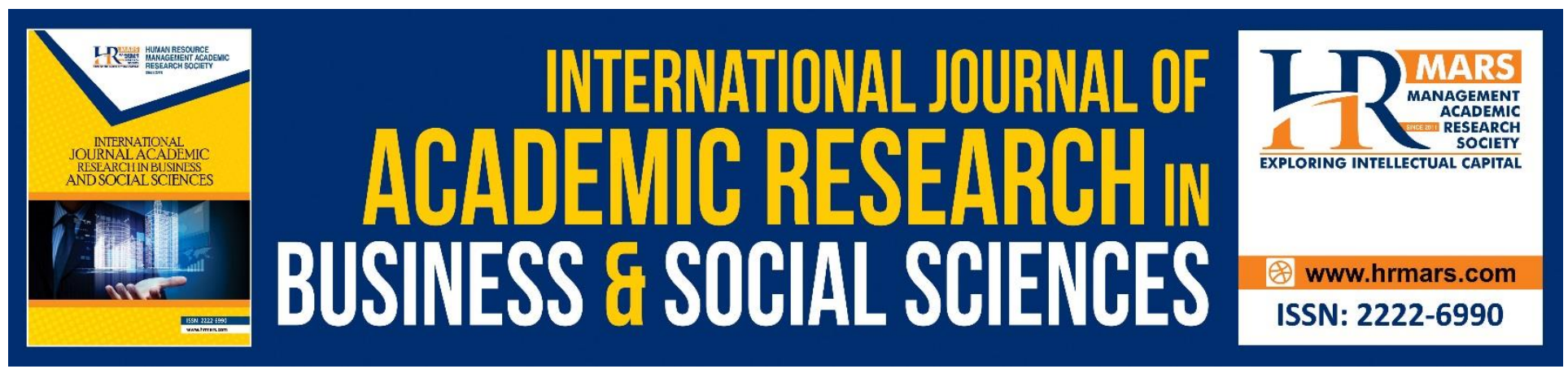

\title{
The Impact of Knowledge Management towards Employee's Job Satisfaction
}

Nor Khadijah Alias, Ahmad Nazri Mansor, Azmi Ab Rahman, Abdul Rahman Ahmad, Ahmad Zam Hariro Samsudin

To Link this Article: http://dx.doi.org/10.6007/IJARBSS/v8-i9/4587

DOI: $\quad 10.6007 /$ IJARBSS/v8-i9/4587

Received: 13 August 2018, Revised: 15 September 2018, Accepted: 29 September 2018

Published Online: 13 October 2018

In-Text Citation: (Alias, Mansor, Rahman, Ahmad, \& Samsudin, 2018)

To Cite this Article: Alias, N. K., Mansor, A. N., Rahman, A. A., Ahmad, A. R., \& Samsudin, A. Z. H. (2018). The Impact of Knowledge Management towards Employee's Job Satisfaction. International Journal of Academic Research in Business and Social Sciences, 8(9), 245-265.

\section{Copyright: (C) 2018 The Author(s)}

Published by Human Resource Management Academic Research Society (www.hrmars.com)

This article is published under the Creative Commons Attribution (CC BY 4.0) license. Anyone may reproduce, distribute, translate and create derivative works of this article (for both commercial and non-commercial purposes), subject to full attribution to the original publication and authors. The full terms of this license may be seen

at: http://creativecommons.org/licences/by/4.0/legalcode

Vol. 8, No. 9, September 2018, Pg. 245 - 265

http://hrmars.com/index.php/pages/detail/IJARBSS

JOURNAL HOMEPAGE

Full Terms \& Conditions of access and use can be found at http://hrmars.com/index.php/pages/detail/publication-ethics 


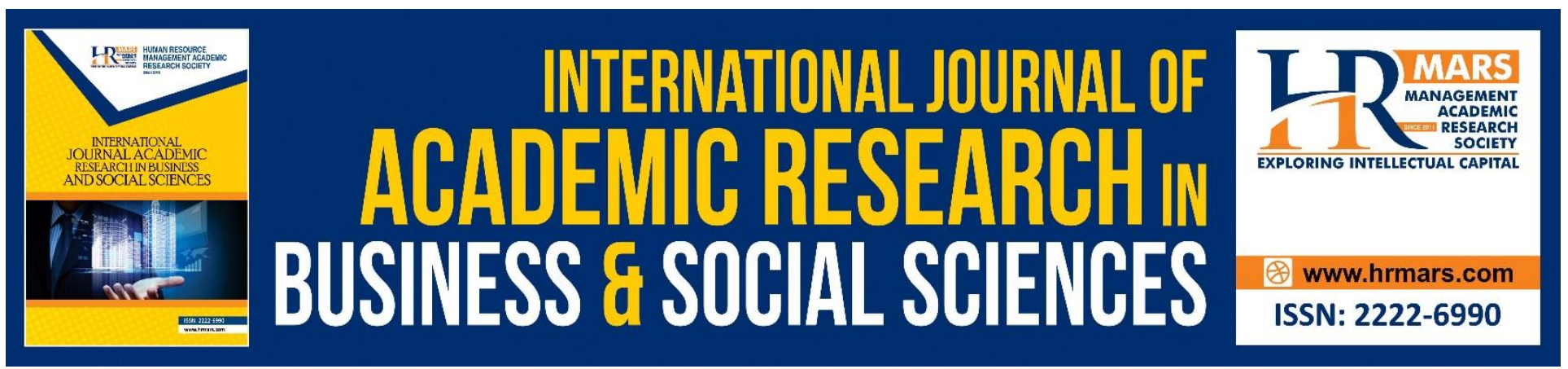

\title{
The Impact of Knowledge Management towards Employee's Job Satisfaction
}

\author{
Nor Khadijah Alias, Ahmad Nazri Mansor, Azmi Ab Rahman, Abdul \\ Rahman Ahmad, Ahmad Zam Hariro Samsudin \\ Faculty of Information Management, Universiti Teknologi MARA (UiTM Selangor), Puncak Perdana \\ Campus, Shah Alam, Malaysia
}

\begin{abstract}
Knowledge management (KM) has been often claimed to be an important ingredient in building competitive advantage in an organization. Based on the previous studies KM adoption in Malaysia is relatively slow. Most organizations in Malaysia are unsure if the promised performance improvement through the implementation of KM practices is just passing a trend. Therefore, this paper aims to meet this need by developing conceptual framework. The conceptual framework for this study is outlined by the process of adapts and adopts from the past research studies. The KM practices that will be discussed in this paper are knowledge acquisition, knowledge sharing, knowledge creation and knowledge retention. It outlines the conceptual framework for this study and find out the factors that will impact the job satisfaction in organization. The conceptual framework section will explained the detailed of the conceptual framework used in this study which consists of four independent variables such as knowledge acquisition, knowledge sharing, knowledge creation and knowledge retention and one dependent variable is job satisfaction. Besides, the review will also cover on the impact of knowledge management practices on employee's job satisfaction. The paper ends with recommendations on further research should be carried out in order to enhance the understanding of the concepts and the effect of KM towards employee's job satisfaction.
\end{abstract}

Keywords: Information Management, Knowledge Management, Knowledge Acquisition, Knowledge Sharing, Knowledge Creation, Knowledge Retention and Job Satisfaction, Library Science.

\section{INTRODUCTION}

Stated by Alavi and Leidner (2001) in a time where knowledge is progressively perceived as an organization's most important resources, many organizations have actualized knowledge management with an end goal to store, capture and disseminate knowledge all over the organization. Kianto et al. (2016), has been proposed that the management of knowledge is for the most part about making, giving, empowering and supporting reasonable learning conditions in an association, to inspire and empower proficient people to utilize and share their insight and make new knowledge. 
According to Davenport and Prusak (1998), knowledge is information joined with understanding, setting, elucidation and reflection. It is a high-esteem type of data that is prepared to be utilized for choices and activities. Organizations need to see correctly which information will give them an upper hand. Wenger et al. (2002) stated contends that it is information or the know-how which will give the association an inventive and focused edge. Information has turned into the way to achievement. It is basically excessively significant as an asset, making it impossible to be left to shot (Wenger et al. 2002).Given the significance of information and its knowledge, numerous organizations are confronted with difficulties of managing themselves considering the requests of the learning driven economy. The point on knowledge management is a humming subject today in many organizations, scholarly establishments, and different parts of the economy. Learning has been seen to have a critical part among the conventional assets of land, work, and capital in making and supporting monetary esteem.

According to Wiig et al. (1997), there has been critical research directed over the previous decade assessing knowledge and how effectively it can be overseen, have recognized as vital key factors in particular, handle, scholarly capital (human), culture and procedure in knowledge management. The discerning of the review is to give a theoretical casing work model to enhance learning administration rehearses through compelling reconciliation of these factors and powerful use of information assets. It will concentrate the integrative impact of procedures, scholarly capital (human), culture and methodology on knowledge management.

\section{An Overview of Knowledge Management}

The dispatch of the idea Knowledge Management (KM) can be followed from the most recent decade of the twentieth century, when it starts and faddish in the business world. Business world perceived the groundbreaking of knowledge in the worldwide economy of the knowledge age. In the new knowledge economy, the care of critical and strategic knowledge and its relentless recovery enable corporate part to addendum focused benefits. The uses of knowledge management have now come to different segments, enveloping Universities, Governmental units, Research and Development area and so forth. (Lee, 2005)

Pruzinsky et al. (2017) stated that knowledge management is about how to outgrowth and empower learned people to utilize and share their insight and make new knowledge. Pruzinsky et al. (2017) analyzes if and how knowledge management practices can be utilized to promote employee job satisfaction in organization. They additionally propose the knowledge management can sustain job satisfaction and encourage high organizational performance.

Knowledge Management (KM) is a gathering of procedures that represent the creation, dispersal, and usage of knowledge in an organization (Newman, 1991). As indicated by IFLA, KM is "a procedure of making (producing, capturing), putting away (protecting, arranging, coordinating), sharing (imparting), applying (executing), and reusing (changing) authoritative knowledge to empower an organization to accomplish its objectives and destinations". It incorporates the management of explicit knowledge (i.e. knowledge that has been classified in databases, pages, reports, and so on.) and sharing of implied knowledge (i.e. aptitudes, mastery, or know-how) (Ajiferuke, 2003). In organizations, explicit knowledge is made inside the association, for example, minutes of gatherings, propositions, reminders rules, reports, and so forth or acquired from extraneous sources, including databases, books, government data, diary articles, and so forth.

Nevertheless, tacit knowledge, embedded in brains of laborers with an extensive knowledge of guidelines and controls, work systems, and so forth (Wijetunge, 2002). Tacit and explicit knolwedge, 
INTERNATIONAL JOURNAL OF ACADEMIC RESEARCH IN BUSINESS AND SOCIAL SCIENCES Vol. 8, No. 9, Sept. 2018, E-ISSN: 2222-6990 @ 2018 HRMARS

both is think as the most critical wellsprings of knowledge of an organization, the management of which ought to be finished with most extreme care and ought to be the prime witticism of any organization (Ajiferuke, 2003).

\section{Knowledge Management in Malaysia}

According to Javed et al. (2012) based on the previous studies has shown when people are happy with their job, they will prepared to do their work systematically and they also more creative and innovative. Stated by Pruzinsky et al. (2017), not many researches on knowledge management and job satisfaction toward organization have been discussed. Therefore, the researcher planned to study in depth about job satisfaction when they are practicing knowledge management as their work task. As indicated by Tsai (2001) employee performance can be upgraded if progressive fragments have focal system positions which urge access to fresh learning developed by various divisions within an organization (Tsai, 2001). By conspicuous verification of information, knowledge management utilizing and their particular effects on employee performance, connections have been recognized KM and performance (Kalling, 2003).

According to Woods (2005) the development and the acknowledgment of knowledge management in Malaysia are limited to multinational organizations (MNC) and government offices and institutions. Small medium enterprises (SMEs) are observed to be less keen on adjusting knowledge management in their organizations. KM practices in Malaysia are still at the exploratory stage where the actual implementation is low. This includes the MSC status organizations which are considered as highly knowledge-structured companies (Norzanah et. al, 2006).

\section{LITERATURE REVIEW}

\section{Concept of Knowledge Management}

The title topic of this conceptual paper is The Impact of Knowledge Management toward Employee's Job Satisfaction. With respect to the subject, researcher needs to think about and investigate on how the knowledge management practices can impact employee's job satisfaction.

Knowledge Management in an organization's capacity to gather, store, share and apply information with a specific end goal to upgrade its survival and achievement. According to Moffet and Hinds (2010) the effective of knowledge management usage liberates representatives. Knowledge worker have adaptability and flexibility to direct their work as per their own particular insight, experience and activity. They bolster each different and in addition by data and information, which resultantly benefits both themselves and the organization.

With the advance in the business field and prospering rivalry, organizations are relying upon its bookkeeping esteem as well as on the commitment of its knowledge (Lin and Tseng, 2005). According to Syed et al. (2004) to most specialists emphatically recommend that the selection and execution of KM practices are principal in building the association's upper hand, for example, capturing and sharing best practices viably overseeing client connections and conveying aggressive insight.

Regardless of the buildup on the positive effect of KM, numerous researchers in Malaysia (e.g. EPU, 2004; Rahman, 2004; Toh et al., 2003) detailed that KM was still generally new in the Malaysian setting. By and large, organizations that had high information power, for example, electrical/hardware, concoction/compost, and administrations showed a more elevated amount of KM practices contrasted with organizations with lower learning force (e.g. material, metal items, nourishment preparing, agrarian items, plastic and elastic items, and others) (EPU, 2004; Toh et al., 2003). By and by, in spite of the ambiguity among industry areas, Malaysian organizations were all 
INTERNATIONAL JOURNAL OF ACADEMIC RESEARCH IN BUSINESS AND SOCIAL SCIENCES Vol. 8, No. 9, Sept. 2018, E-ISSN: 2222-6990 @ 2018 HRMARS

the while lingering behind their remote partners from driving economies (EPU, 2004). Rahman (2004) who overviewed 303 training and government associations found that exclusive 46 percent (139 organizations) had built up formal activities of KM. Irritatingly, just a little bit of the 46 percent have really started usage (32 organizations) and observing (18 organizations) though larger part of associations were still in the underlying phases of researching, inspecting, get ready or setting spending plan.

The slow implementation is not on the grounds that organizations didn't know about KM. Rather, most Malaysian organizations were embracing the 'sit back and watch' approach concerning the execution of KM ventures inside their organizations (Woods, 2005) as they didn't know about the potential advantages of KM. The critical absence of experimental confirmation of the relationship between KM practices and job satisfaction, additionally powers this reluctance among organizations to grasp KM. A few researchers who got empirical support utilizing the contextual analysis strategy (e.g., Zaim, Tatoglu, and Zaim, 2007) underlined that albeit positive connections were found between KM practices and KM extend execution, the discoveries couldn't be summed up to a more extensive populace. Henceforth, this exploration expects to fill this hole by giving exact approval that there is to be sure a connection between these components for most organizations particularly for information based firms. Knowing so would encourage the reception of suitable KM practices to encounter expanded competitive advantage.

\section{KM Practices}

$\mathrm{KM}$ alludes to distinguishing and utilizing the aggregate information in an organization to offer assistance the organization contends (von Krogh, 1998). According to Lee et al. (2003) KM supposedly consists of knowledge process such as knowledge creation, acquisition, sharing, transfer and application.

Nonaka and Takeuchi (1995) stated isolated KM process into knowledge creation, storage and transfer. KM process also has been proposes by Demarest (1997) and Pruzinsky et al. (2017) such as knowledge creation, knowledge codification, knowledge acquisition, knowledge sharing and knowledge retention.

\section{Knowledge Acquisition}

According to Zahra and George (2002) knowledge acquisition remains for authoritative practices went for a collecting data from extra-organizational sources. External networks and collaborative arrangements are crucial sources of knowledge for a wide range of organization. Clients frame a particularly imperative gathering from which knowledge ought to be gained if the organization is succeeded. For example, customer feedback systems, data mining, business intelligence and collaboration with partners and research institutions are typical of highly developed knowledge acquisition practices.

Knowledge acquisition is a continuous and dynamic process. Knowledge acquisition includes the ability to devise original thoughts, bits of knowledge and arrangements and link it inside the organization (Bhatt, 2001; Bose, 2004; Tiwana, 2003).

\section{Knowledge Sharing}

According to King (2007) has also discovered that sharing or dissemination of knowledge is one of the important components of knowledge management practices. It decides the step to which representatives will impart their thoughts and profitable knowledge to supervisors and colleagues 
INTERNATIONAL JOURNAL OF ACADEMIC RESEARCH IN BUSINESS AND SOCIAL SCIENCES Vol. 8, No. 9, Sept. 2018, E-ISSN: 2222-6990 @ 2018 HRMARS

for achieving their tasks and getting better output. On the other hand, it likewise speaks to the procedure utilized by workers for coursing or trading data inside various divisions and individuals from the association (Becerra-Fernandez and Sabherwal, 2014).

Supported by Awad et al. (2007) knowledge management is the procedure by which organizations accumulate, create, offer and utilize information in a viable path for accomplishing particular targets. It is essentially a multidisciplinary procedure as well as distinctive instruments and methodologies. The human factor is one of the important factors to be considered as it likewise relies upon aims of employees to share knowledge with others in order to maintaining effective knowledge management practices.

According to Trivellas et al. (2015) based on the previous studies have suggested that without commitment from employees, organization can't keep up successful knowledge management practices if employees didn't sharing knowledge to each other. This study also supported by King (2007) although a few studies have noticed the part of organizational culture and structure in knowledge sharing, they need to discover its effect on employee's job satisfaction.

\section{Knowledge Creation}

Knowledge creation refers to the organization's capacity to grow new and helpful idea and arrangements with respect to different parts of organizational activities, from technological processes, products and administrative practices. According to Eisenhardt and Martin (2000) knowledge creation is a main factor in empowering supported performance in turbulent situations. Knowledge creation is created when an organization and its individuals learn and improve the skill or knowledge. According to Scharmer (2001), knowledge creating organizations arrange for the development of employee potential and self-rising above knowledge to develop profoundly new experiences and advance development and thought improvement at all levels of the organization.

\section{Knowledge Retention}

Kianto et al. (2016) simply defines knowledge retention as an activities related to overseeing employee turnover and the related loss of expert knowledge which refer a key organization asset. Expert knowledge can be lost when employees leave the organization for some reason. As baby boomers retire, attracting and maintaining the best employees will turn into a significantly all the more squeezing challenge concerning knowledge retention. (Kianto, 2016)

\section{Job Satisfaction}

Spector (1994) stated, job satisfaction can be described as how much people like (fulfillment) or dislike (dissatisfaction) their occupations. Job satisfaction can add to mental success at work (Robbins et al., 2003). According to Shaikh et al. (2012), occupation fulfillment insinuates the state in which employees take delight from their work or the positive and enthusiastic state of the worker after appraisal of his or her occupation and performance.

According to Fritzsche and Parrish (2005) the significance of job satisfaction changes from the sentiments an employee has about his or her occupation. According to Locke (1969) job satisfaction has likewise been characterized as "a component of the apparent connection between what one needs from one's employment and what one sees it as advertising" and as the degree to which a worker feels decidedly or contrarily towards his or her occupation (Locke, 1976). The term job 
INTERNATIONAL JOURNAL OF ACADEMIC RESEARCH IN BUSINESS AND SOCIAL SCIENCES

Vol. 8, No. 9, Sept. 2018, E-ISSN: 2222-6990 @ 2018 HRMARS

satisfaction is near the idea of worker satisfaction. As stated by Grant et al. (2007), employee satisfaction is the general nature of a worker's involvement and working at work. The definition incorporates three measurements of satisfaction: mental, physical and social. Satisfaction is a basic calculate both individual and hierarchical execution. The effect of poor satisfaction is reflected in under-execution, truancy, presentism, wiped out leave and turnover (Baptiste, 2008). Supported by Vroom (1964) job satisfaction likewise identifies with the exchange of inspiration, where the source of job satisfaction can be associated particularly to social having a place, confidence and selfactualization.

\section{Knowledge Management in Organization}

Much the same as the expression "knowledge," the expression "Knowledge Management" (KM) is moreover hard to characterize. Truly, the setting in which KM is utilized and the sorts of issues it is utilized to comprehend at last decide its proper definition for any organization. What is most essential, in any case, is that each of these definitions centers on the KM to enhance methods for working together and making esteem. Despite the fact that KM has gotten an awful name in a few circles due to the fizzled cases of experts out to make a quick dollar, actually KM is digging in for the long haul. Spiegler (2000), tending to the issue of whether KM is "another thought" or "reused idea," established that KM is really another thought separated and isolate from data frameworks, choice emotionally supportive networks, and data management of the past because of the uniqueness of the "knowledge" component.

The significance of knowledge has been perceived all through history. Sir Francis Bacon wrote in 1597, "Knowledge is power." More as of late, association s have started to go up against a comparable view perceiving that "information," rather than "data" or "information," is the most deliberately noteworthy authoritative asset (Drucker, 1993; Earl, 2001; Nidumolu, et al, 2001; Zack, 1999) and the way to future association achievement, upper hand (Korn/Ferry, 2000; KPMG, 2000) and development (Amidon, 1997; KPMG, 2000). According to Becerra-Fernandez (2001) the broadly held conviction that the wealthiest asset of today's organization is the learning living independently and by and large among workers mirrors the significance of procedures for advancing the creation, sharing, what's more, utilizing of learning. Fahey and Prusak (1998), stated notwithstanding the developing significance of knowledge and learning forms, it has been perceived that organizations don't oversee either exceptionally well. The endeavor to concentrate on and better oversee learning and information forms has prompted the development of the idea and routine with regards to (KM).

\section{Knowledge Management and Job Satisfaction}

Bimpitsos and Petridou, (2012) stated, organizations work in a domain described by vulnerability, flimsiness and change that incite the appearance of different difficulties. Such condition incorporates many elements as expanded globalization, quick mechanical change, and the developing requirement for qualified employees and enhanced performance (Vanhala and Stavrou, 2013). Savaneviciene and Stakeviciute (2011) stated this strengths organization to attempt and adventure the assets at its transfer with a specific end goal to accomplish an upper hand.

According to Glisson and Durick (1988), the prerequisites for high job satisfaction have been widely studied, and the validated antecedents include, for example, job design, skill variety and role ambiguity. However, the KM issues have not yet been included among the many job satisfaction factors to be examined. In general, it seems that KM literature has only rarely addressed in previous study. 
INTERNATIONAL JOURNAL OF ACADEMIC RESEARCH IN BUSINESS AND SOCIAL SCIENCES Vol. 8, No. 9, Sept. 2018, E-ISSN: 2222-6990 @ 2018 HRMARS

Stated by Dominguez (2011) KM viewed as basic elements adding to an organization's satisfaction. Supported by Othman (2009) utilizing KM in a vital way is required to beat the distinctive difficulties organizations confront. In this way, viably dealing with these assets is of significance to all association (Juhdi et al., 2011). According to Ortega-Parra and Sastre-Castillo (2013) dealing with the KM of an organization requires the utilization of various practices that assume a huge part in helping organizations make and manage the performance they want as they impact the states of mind and practices of employees (Lew, 2011). Supported by Yew (2013) organizations look to build up a conferred workforce (Yew, 2013) and finding the most ideal approach to hold their employees from turnover (Riveros and Tsai, 2011).

As stated by Tiwari and Saxena (2012), an organization's conduct can be enhanced in such territories as staff duty, competency, and adaptability by dealing with the KM accessible in that organization. All the more particularly, it is accounted for that few KM practices can influence employee responsibility and inspiration these incorporate enrollment and choice, preparing and improvement, performance evaluation, cooperation, and remuneration and reward (Fong et al., 2011).

As stated by Fong et al. (2011), knowledge lives in the psyches of employees however that knowledge can be effectively lost if employees choose to leave the organization. Due to that reason organizations look to enhance the (KM) procedures of securing, appropriation, understanding, and hierarchical memory (Jimenez-Jimenez and Sanz-Valle, 2013). The reason for this study is to research the relationship between KM and employee's job satisfaction, hierarchical responsibility from one viewpoint and their organization with knowledge management, on the other hand. To accomplish this reason, the principal segments examine the hypothetical foundation, inquire about system, examine model, and theories.

\section{Models and Frameworks of Previous Study}

In order to guide this study a theoretical or conceptual model must be drawn in light of five past studies with the goal that it can give guidance for this study. There are five models or framework that have been chosen and will be discussed about in this section. These models are important as it will give a few bits of knowledge and thoughts on the choice components on impact of KM toward employee performance in organization.

Singh and Sharma (2011) proposed a research framework on the factors that could effect on the employee's satisfaction toward knowledge management. The research framework is shown in the Figure 2.1 as follows:

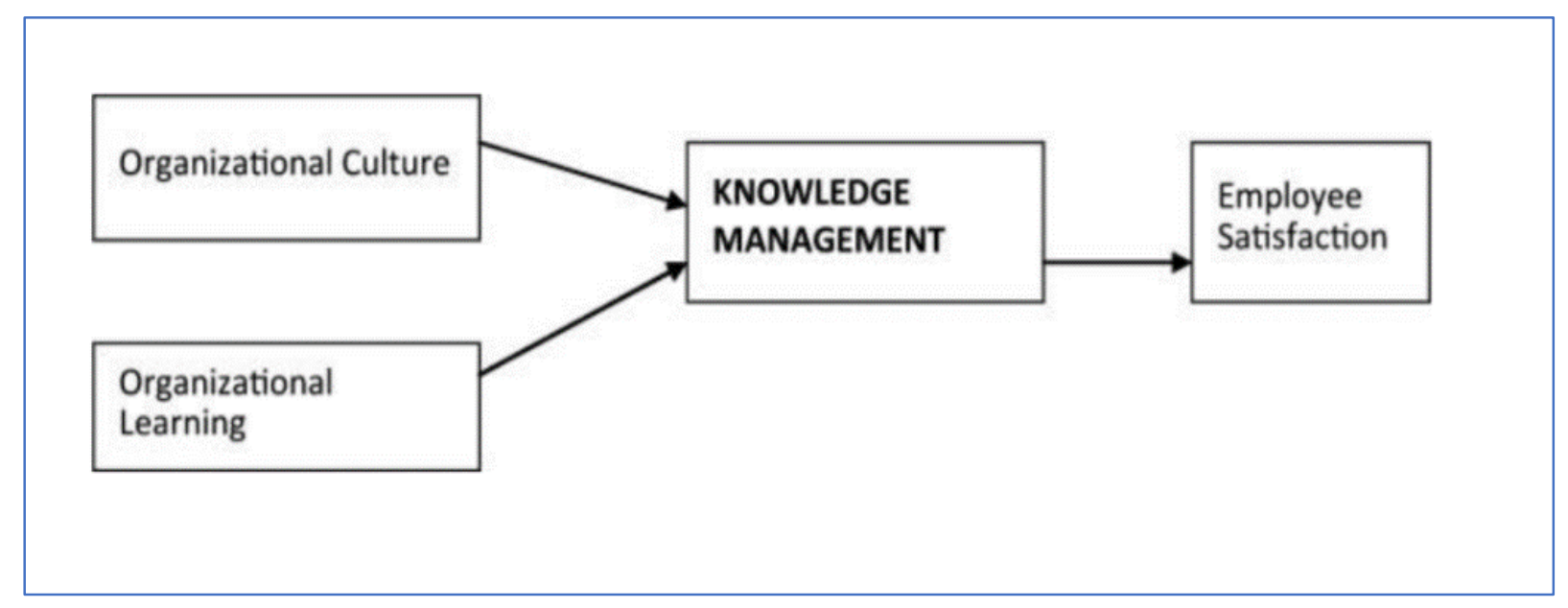


INTERNATIONAL JOURNAL OF ACADEMIC RESEARCH IN BUSINESS AND SOCIAL SCIENCES Vol. 8, No. 9, Sept. 2018, E-ISSN: 2222-6990 @ 2018 HRMARS

Figure 2.1: Relationship between knowledge management and employees' satisfaction

Based on this framework there are two independent variables, one mediating variable and one dependent variable. The two independent variables are organizational culture and organizational learning, while the knowledge management is a mediating variable and employee satisfaction is dependent variable. Researchers found based on the studied that employees that satisfied with their work are more innovative, inventive and always ready to run their work in order to achieve success. In contrast, employees that are not satisfied with their work, they are having ethical an ability issues to complete the task and work commitment.

Based on the study, researchers developed three main hypotheses. Hypothesis 1: There is positive correlation between Organizational Culture and Knowledge Management, Hypothesis 2: There is positive correlation between Organizational Learning and Knowledge Management and Hypothesis 3: Knowledge Management enhances Employee Satisfaction.

Koohang et al. (2017) proposed a research framework on the relationship between leadership, trust and knowledge management and organizational performance. The research framework is shown in the Figure 2.2 as follows;

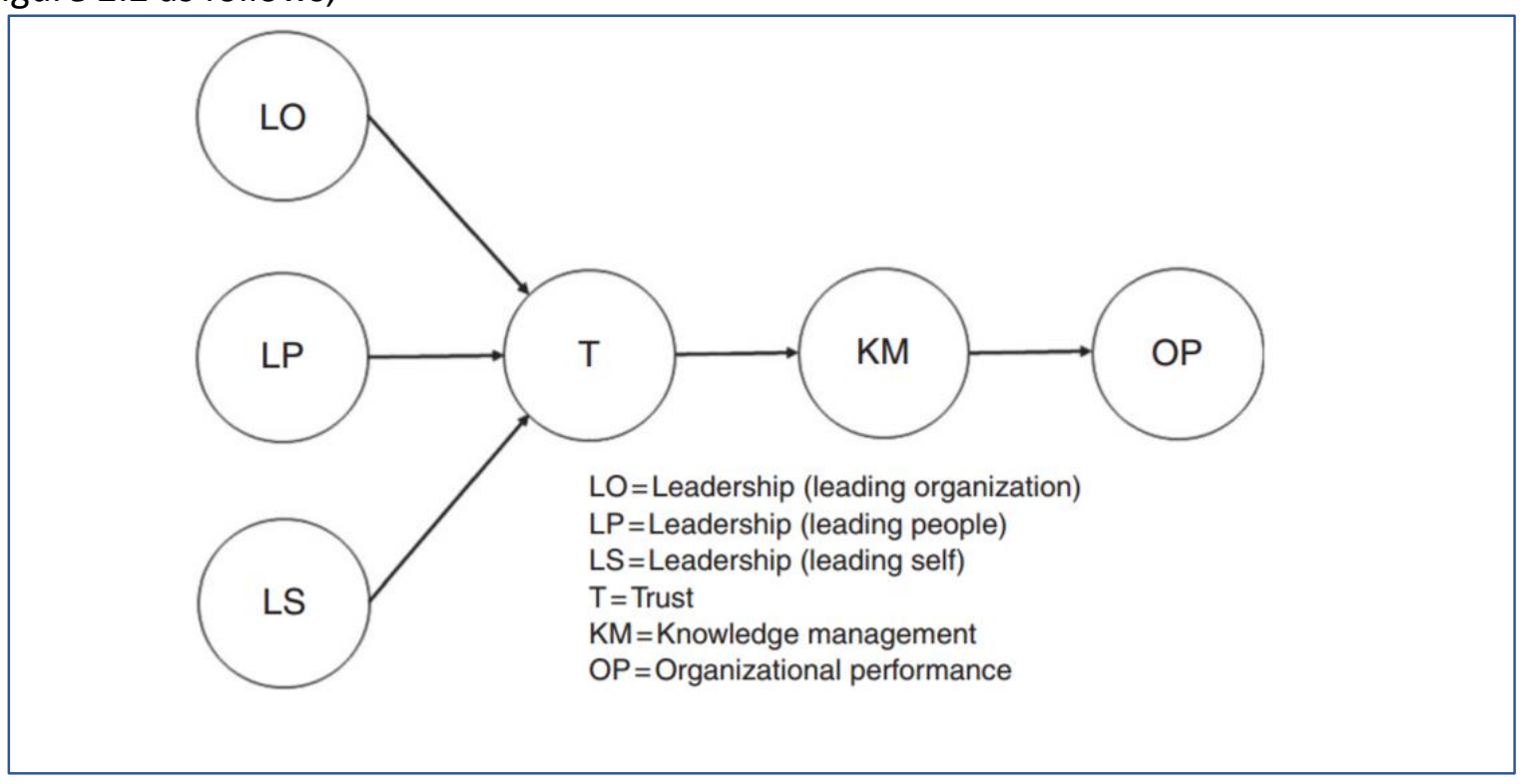

Figure 2.2: Relationship between leadership, trust, knowledge management and organizational performance.

The purpose of this study is to examine the impact of leadership, trust and knowledge management and organizational performance. The framework construct six variables such as leading organization, leading people, leading self, trust, knowledge management and organizational performance identified by researchers. According to researcher effective leadership empower and cultivates trust in people and based on the result, employee are motivated to assume more responsible towards their work.

Jayasingam et al. (2014) proposed a research framework on the relationship between knowledge management practices and knowledge performance in organization. The research framework is shown in the Figure 2.3 as follows: 


\section{KM practices \\ Knowledge acquisition \\ Knowledge dissemination Knowledge utilization \\ KM performance \\ -Customer \\ -Human resource \\ -Financial \\ -Process \& Technology}

Figure 2.3: Relationship between KM practices and KM performance

Based from this framework there are three independent variables of KM practices and four dependent variables of KM performance identified by researchers. The three independent variables are knowledge acquisition, knowledge dissemination and knowledge utilization while the four dependent variables are customer, human resource, financial, process and technology.

With reference to the literature and the research framework, researcher developed two hypotheses. The hypothesis 1 is knowledge acquisition practices positively influences KM project performance and hypothesis 2 is knowledge dissemination practices positively influences KM project performance. Kianto et al. (2016) proposed a research framework on the relationship between KM practices and job satisfaction. The research framework is shown in the Figure 2.4 as follows:

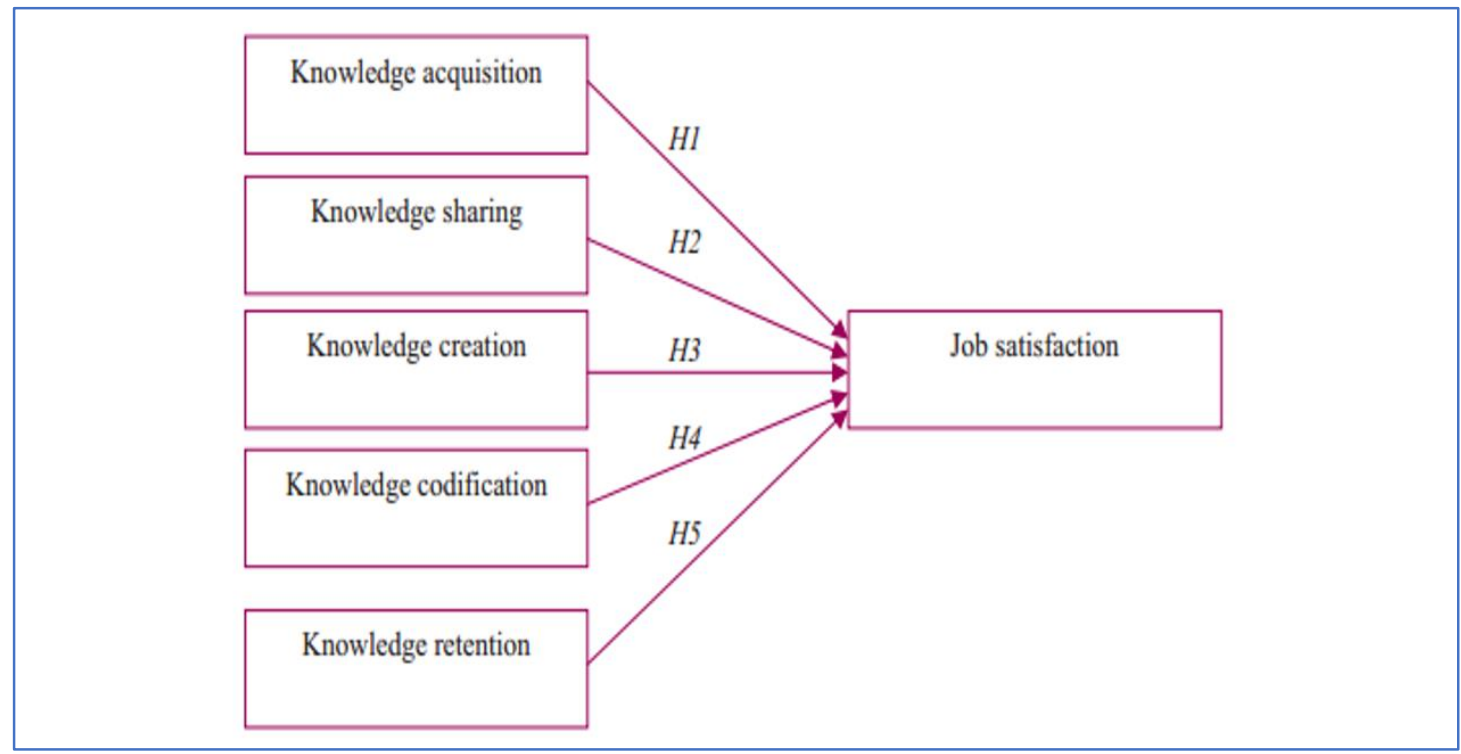

Figure 2.4: Relationship between KM practices and job satisfaction

The researcher proposes that the five practices of $\mathrm{KM}$ such as knowledge acquisition, knowledge creation, knowledge sharing, knowledge codification and knowledge retention will improve the likelihood of employee job satisfaction. According to Kianto et al. (2016) job satisfaction, in turn, is related to high performance at both the individual and organizational levels. To achieve the goals of 
INTERNATIONAL JOURNAL OF ACADEMIC RESEARCH IN BUSINESS AND SOCIAL SCIENCES Vol. 8, No. 9, Sept. 2018, E-ISSN: 2222-6990 @ 2018 HRMARS

this study, researcher developed three main hypotheses. Hypothesis 1 is knowledge acquisition will be positively associated with job satisfaction, hypothesis 2 is knowledge sharing will be positively associated with job satisfaction, hypothesis 3 is knowledge creation will be positively associated with job satisfaction, hypothesis 4 is knowledge codification will be positively associated with job satisfaction and lastly hypothesis 5 is knowledge retention will be positively associated with job satisfaction.

Obeidat et al. (2014) proposed a research framework on the relationship between HR practices on KM process within organization. The research framework is shown in the Figure 2.5 as follows:

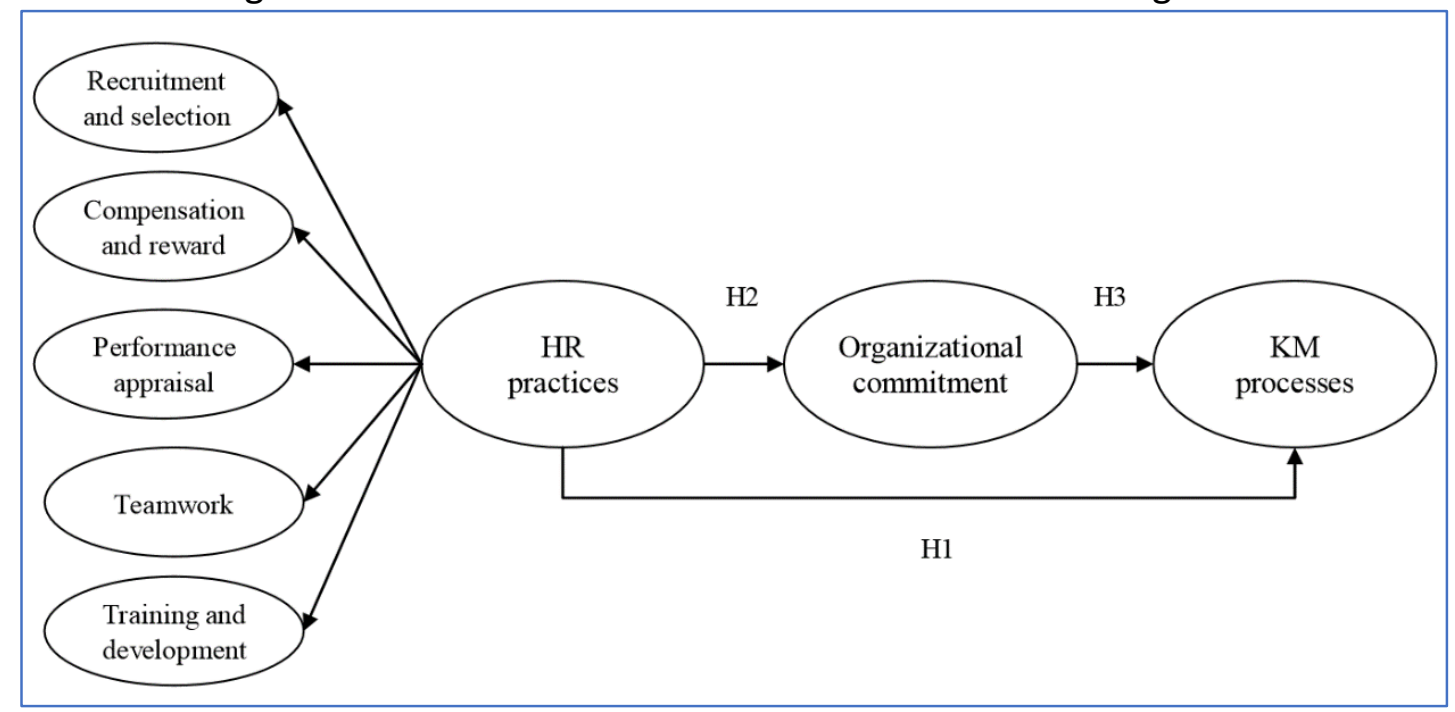

Figure 2.5: Relationship between HR practices on KM process within organization

The objective of this study is to investigate the relationship between HR practices on KM process within organization.

Based on Obeidat et al. (2014) study, HR practices were measured utilizing recruitment methods, training and development, performance appraisals, and reward systems. Organizational commitment was measured using three dimensions of affective commitment, continuance commitment, and normative commitment. Finally, knowledge management process was measured using four phases of knowledge acquisition, knowledge distribution, knowledge interpretation, and organizational memory. Researcher developed three main hypotheses to achieve the goals of this study which consist of hypothesis 1: There is a relationship between human resource management practices and knowledge management process, hypothesis 2: There is a relationship between human resource management practices and organizational commitment and hypothesis 3: There is a relationship between organizational commitment and knowledge management process.

\section{Theoretical Framework and Hypothesis}

The conceptual framework used for this paper is outlined by the process of adapts and adopt from past studies and literatures. The knowledge management practices that has been adapted as independent variable (IV) is knowledge acquisition, knowledge sharing, knowledge creation and knowledge retention. While for dependent variable (DV) is employee's job satisfaction as the indicator. The definition of every variable can be found in this section alongside the variable description and relation with other study. In this study the relationship between the independent 
INTERNATIONAL JOURNAL OF ACADEMIC RESEARCH IN BUSINESS AND SOCIAL SCIENCES Vol. 8, No. 9, Sept. 2018, E-ISSN: 2222-6990 @ 2018 HRMARS

variables and dependent variable will be examined and hypotheses are proposed in this section. The research framework is shown in the Figure 2.6 as follows;

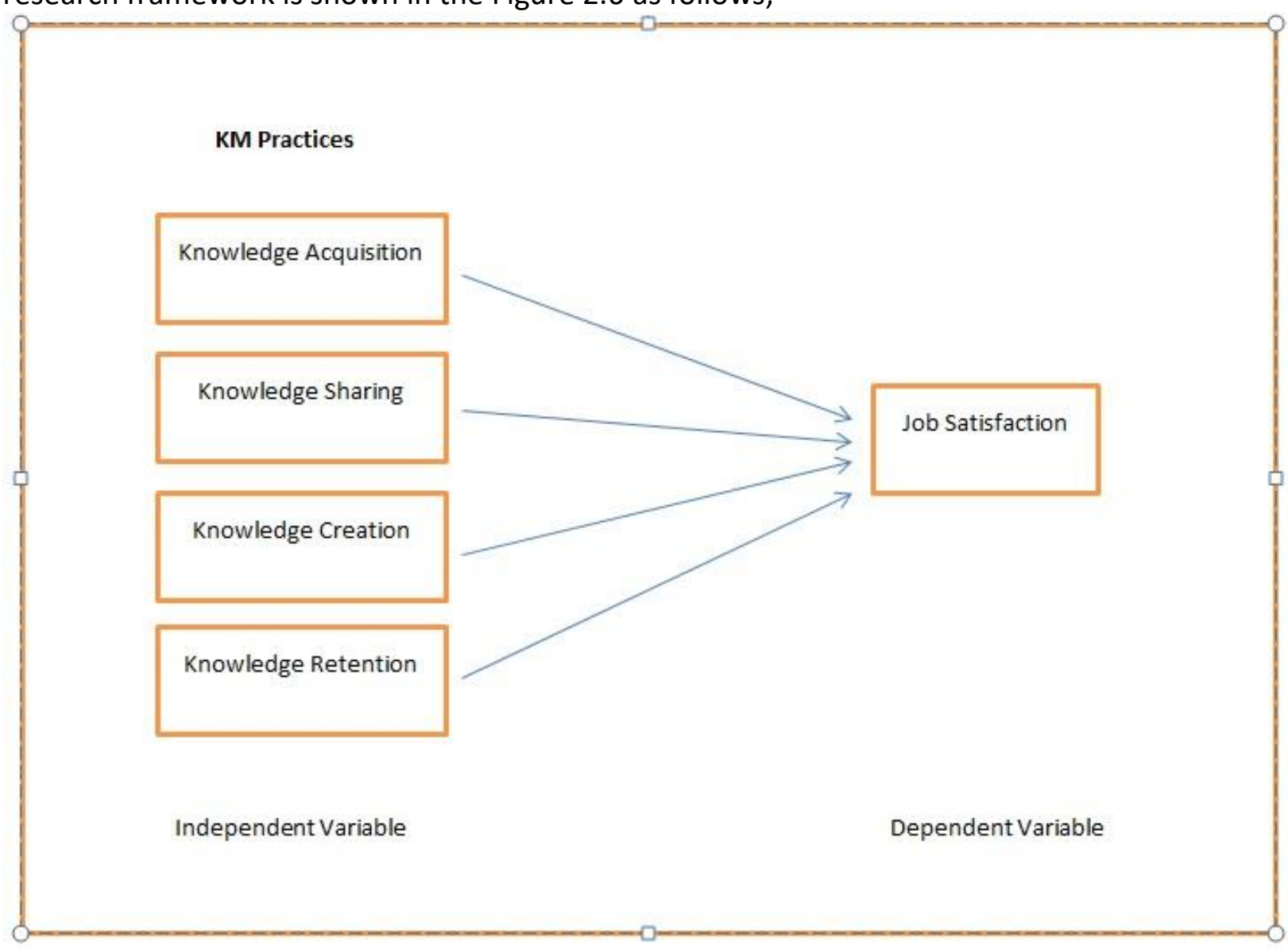

Figure 2.6: Research Framework

\section{Knowledge Acquisition and Job Satisfaction}

Knowledge acquisition (creation) includes the capacity to devise original thoughts, bits of knowledge and arrangements and incorporate it within the organization (Tiwana, 2003).

Based on study from Jayasingam et al. (2014), was used the KM scale developed by Darroch (2003) to measure KM practices employed within organizations studied. This scale consists of knowledge acquisition. According to Jayasingam et al. (2014) as KM outcome is difficult to measure, this study focuses on the performance of KM projects as perceived by individuals who experience the consequences of KM projects rather than adopting objective measures.

According to Bose (2004) KM projects are ongoing and continuous projects, measures of performance of KM projects should be viewed as factors of the organization's development or improvement and not as the end by themselves. Therefore, the extent of improvement is employed as performance measurement rather than level of achievement.

Then the researcher argues that the finding between knowledge acquisition and employee's job satisfaction. Based on the above study, the researcher therefore proposed for the following hypothesis

\section{- Hypothesis 1: There is significant relationship between KA and JS}




\section{Knowledge Sharing and Job Satisfaction}

Knowledge sharing is the exchange of knowledge between people, among groups, organizational units and organizations. (Nonaka and Takeuchi, 1995).Based on the finding from Saeed (2016), the relationship between job satisfaction and knowledge sharing is highly correlated with value of 0.934. Based on the findings, Saeed (2016) suggested that higher is the knowledge sharing the higher will be employee performance. When employees are encouraged to share knowledge with others employees, they get more opportunities to develop new ideas, explore information and contribute effectively in attaining organization's objectives. This is also evident by this study's findings that employee seek to share knowledge with others aiming to make significant improvement in their job performance. This result in line with Trivellas et al (2015) has also explored positive association between knowledge sharing and job satisfaction.

Then the researcher argues that the finding between knowledge sharing and employee's job satisfaction. Based on the above study, the researcher therefore proposed for the following hypothesis

\section{- Hypothesis 2: There is significant relationship between KS and JS}

\section{Knowledge Creation and Job Satisfaction}

Knowledge creation refer to the organization's ability to develop new and valuable thoughts and solution in regards to different parts of organizational activities, from items and technology process to management practices (Nonaka, 1991, Kianto and Andreeva, 2011).

Based on the study from Prunzinsky et al. (2016), knowledge creation is not factor that affect job satisfaction. This might be because of the context of the study. It is possible that the nature of the work carried out in this municipal organization requires neither knowledge acquisition (especially from sources or partners outside the organization) nor the creation of the new knowledge. Such activities are not encouraged by either support or reward in the organization. Consequently, they have no effect on job satisfaction.

Then the researcher argues that the finding between knowledge creation and employee's job satisfaction. Based on the above study, the researcher therefore proposed for the following hypothesis

\section{- Hypothesis 3: There is significant relationship between $\mathrm{KC}$ and JS}

\section{The Relationship between Knowledge Retention and Job Satisfaction}

Knowledge retention refers to activities related to managing personnel turnover and the associated loss of expert knowledge, a key strategic resource. (Kianto, 2016).

Knowledge retention was the key KM process for this group, meaning that knowledge continuity and preservation are important for ensuring their work satisfaction. This is to be expected as the strategic steering of an organisation requires an extensive and deep understanding of its history to construct path-dependent strategies. It is also important for this group to understand external forces and the institutional and legislative environment in which the organisation operates.

Based on study by Kianto et al. (2016) the remaining of knowledge retention and had connections with job satisfaction. Specifically, the results indicate that intra-organisational knowledge sharing is the key KM process, promoting job satisfaction for most employee groups. 
INTERNATIONAL JOURNAL OF ACADEMIC RESEARCH IN BUSINESS AND SOCIAL SCIENCES Vol. 8, No. 9, Sept. 2018, E-ISSN: 2222-6990 (c) 2018 HRMARS

Then the researcher argues that the finding between knowledge creation and employee's job satisfaction. Based on the above study, the researcher therefore proposed for the following hypothesis

- Hypothesis 1: There is significant relationship between KR and JS

\section{Conclusion}

In conclusion, this conceptual paper gives a broad comprehension on the knowledge management and job satisfaction. The literatures from past studies are looked into in view of research papers and conceptual papers written by scholars and researchers in this field. Every variable utilized as a part of this study as of now been analyzed. This study investigates further keeping in mind the end goal to give better clarification and comprehension about the impact of knowledge management towards employee's job satisfaction from different past reviews. A theoretical review audit is additionally done to study the components that may be incorporated into this study which covers the knowledge management practices and also job satisfaction. In view of the perusing, employee's satisfaction can be shown by measuring the job satisfaction of a person through KM practices. Utilizing the idea of adopts and adapt, a conceptual framework is recommended as the model to lead this study. Further research should be carried out in order to enhance the understanding of the concepts and the effect of KM towards employee's job satisfaction.

\section{References}

Ajiferuke, I. (2003). Role of information professionals in knowledge management programs: empirical evidence from Canada, Informing Science, 6,247-257.

Alavi, M., \& Leidner, D. E. (2001). Review: Knowledge management and knowledge management systems: Conceptual foundations and research issues. MIS Quarterly, 25(1), 107-136.

Amidon, D. M. (1997). Innovation strategy for the knowledge economy: the ken awakening. Boston: Butterworth-Heinemann.

Awad, E., \& H. Ghaziri. (2007). Knowledge Management. Pearson Education India

Bacon, Sir Francis. 1597/2002. Religious meditations: Of heresies. In Francis Bacon: The major works, ed. Vickers. Oxford: Oxford World's Classics.

Becerra-Fernandez., I. \& Sabherwa I., R. (2014). Knowledge Management: Systems and Processes. Routledge.

Bhatt, G. D. (2001). "Knowledge management in organizations: examining the interaction between technologies, techniques and people," Journal of Knowledge Management, (5),6875.

Bounfour, A. (2003). The management of intangibles: The organisation's most valuable assets (16): Psychology Press 
INTERNATIONAL JOURNAL OF ACADEMIC RESEARCH IN BUSINESS AND SOCIAL SCIENCES Vol. 8, No. 9, Sept. 2018, E-ISSN: 2222-6990 (C) 2018 HRMARS

Bose, R. (2004). "Knowledge management metrics," Industrial Management and Data Systems, (104), 457-468.

Bimpitsos, C., \& Petridou, E. (2012). A transdisciplinary approach to training: preliminary research findings based on a case analysis. European Journal of Training and Development, 36(9), 911-929.http://dx.doi.org/10.1108/03090591211280964

Darroch, J. (2005). "Knowledge management, innovation and firm performance," Journal of Knowledge Management, 9 (3). 101-115.

Davenport, T. H.,\& Prusak, L. (1998) Working knowledge: How organizations manage what they know, Harvard Business School Press, Boston.

Davenport, T. H., \& Prusak, L. (2000). "Working knowledge," Cambridge: Harvard Business School Press.

Demarest, M. (1997), “Understanding knowledge management”, Long Range Planning, 30(3),374-384.

Dominguez, A. A. (2011). The impact of human resource disclosure on corporate image. Journal of Human Resource Costing \& Accounting, 15(4), 279-298. http://dx.doi.org/10.1108/14013381111197225

Drucker, P. F. (1993). Post-Capitalist Society. New York: Harper Collins Publishers, Inc.

Drucker, P. F. (1998). On the Profession of Management. Boston: Harvard Business School Publishing.

Earl, M. (2001). Knowledge Management Strategies: Toward a Taxonomy. Journal of Management Information Systems, 18(1), 215-233.

Eisenhardt, K. and Martin, J. (2000), “Dynamic capabilities: what are they?", Strategic Management Journal, 21(10/11),1105-1121

EPU (2004). "Knowledge content in key economic sectors in Malaysia". Economic Planning Unit, Prime Minister's Department Malaysia.

Fahey, L., Prusak, L. (1988), "The Eleven Deadliest Sins Of Knowledge Management", California Management Review, Vol. 40, No. 3

Fong, C., Ooi, K., Tan, B., Lee, V., \& Chong, A. (2011). HRM practices and knowledge sharing: an empirical study. International Journal of Manpower, 32(5/6), 704-723. http://dx.doi.org/10.1108/01437721111158288

Fritzsche, B.A. and Parrish, T. (2005), "Theories and research on job satisfaction", in Brown, 
INTERNATIONAL JOURNAL OF ACADEMIC RESEARCH IN BUSINESS AND SOCIAL SCIENCES Vol. 8, No. 9, Sept. 2018, E-ISSN: 2222-6990 (C) 2018 HRMARS

S.D. and Lent, R.W. (Eds), Career Development and Counseling: Putting Theory and Research to Work, Wiley, Hoboken, NJ.

Fong, C., Ooi, K., Tan, B., Lee, V., \& Chong, A. (2011). HRM practices and knowledge sharing: an empirical study. International Journal of Manpower, 32(5/6), 704-723. http://dx.doi.org/10.1108/01437721111158288

Glisson, C.V. and Durick, M. (1988), "Predictors of job satisfaction and organizational commitment in human service organizations", Administrative Science Quarterly,33(1) 61-68.

Grant, A. M. (2007). Relational job design and the motivation to make a prosocial difference. Academy of Management Review, 32(2), 393-417.

Hackman, J. R., \& Oldham, G. R. (1976). Motivation through the design of work: test of a theory. Organizational Behavior and Human Performance, 16(2), 250-279

IFLA KM Section Brochure (2012). (Accessed on 11.08.2014), http://www.ifla.org/files/assets/km/publications/KM\%20brochure\%202012.pdf.

Jayasingam, S., Jantan, M.,Ansari,M.A. \& Ramayah, T. (2014). “Knowledge management practices and performance: Are they truly linked?" Creating Global Economies through Innovation and Knowledge Management: Theory \& Practice.

Javed, M., Rafiq, M., Ahmed, \& M. Khan, M. (2012). Impact of HR Practices on Employee Job Satisfaction in Public Sector Organizations of Pakistan. Interdisciplinary journal of contemporary research in business, 4(1), 348-363.

Jimenez-Jimenez, D., \& Sanz-Valle, R. (2013). Studying the effect of HRM practices on the knowledge management process. Personnel Review, 42(1), 28-49. http://dx.doi.org/10.1108/00483481311285219

Juhdi, N., Pa'wan, F., Hansaram, R. M., \& Othman, N. A. (2011). HR practices, organizational commitment and turnover intention: A study on employees in Klang Valley, Malaysia. Recent Researches in Applied Economics, 30-36.

Kalling, T. (2003). Knowledge management and the occasional links with performance. Journal of knowledge Management, 7(3), 67-81.

Kianto, A. and Andreeva, T. (2011), “Does KM really matter? Linking KM practices, competitiveness and economic performance", paper presented at the International Forum on Knowledge Asset Dynamics (IFKAD) 2011, 15-17 June, Tampere.

Kianto, A., Vanhala, M., and Heilmann, P. (2016) "The impact of knowledge management on job satisfaction", Journal of Knowledge Management, 20(4),621-636, doi: 10.1108/JKM-102015-0398 
INTERNATIONAL JOURNAL OF ACADEMIC RESEARCH IN BUSINESS AND SOCIAL SCIENCES Vol. 8, No. 9, Sept. 2018, E-ISSN: 2222-6990 (C) 2018 HRMARS

King, W. (2007). A research agenda for the relationships between culture and knowledge management, Knowledge and Process Management, 14(3), pp. 226-236

Koohang,A.,Paliszkiewicz,J.\& Goluchowski,J. (2017) The Impact of leadership on trust, knowledge management and organizational performance:A research model. Industrial Management \& Data Systems,117 (3), 521-537.

Korn/Ferry International, Mohrman, S., \& Finegold, D. (2000). Strategies for the Knowledge Economy: From Rhetoric to Reality. University of Southern California's Marshall School of Business, Center for Effective Organizations.

KPMG Consulting. (2000). Knowledge Management: Common Sense, But Is It Also Common Practice? KPMG Consulting Knowledge Management Survey 2000. KPMG Consulting.

Lin,C.,\& Tseng,S.M (2005) "The implementation gaps for the knowledge management system", Industrial Management \& Data Systems, 105(2), 208-222, https://doi.org/10.1108/02635570510583334

Lee, H. W. (2005).Knowledge management and the role of libraries.

Lee, H. and Choi, B. (2003), "Knowledge management enablers, processes, and organizational performance: an integrative view and empirical examination", Journal of Management Information Systems,20 (1), 179-228.

Lew, T. Y. (2011). Affective organizational commitment and turnover intention of academics in Malaysia. Proceedings of the International Conference on Business and Economics Research, Kuala Lumpur, Malaysia.

Locke, E. A. (1969). What is Job Satisfaction? OB and Human Performance,(4),309-336.

Locke, E. A. (1976). The Nature and Causes of Job Satisfaction. In Dunnette, M.D. (Ed.), Handbook of the Industrial and Organizational Psychology. Chicago: Rand McNally.

Ming Yu, C. (2002). "Socializing knowledge management: The influence of the opinion leader," Journal of Knowledge Management Practice, (3),76-83.

Moffet, H \& Hinds, A., (2010). 'Assessing the impact of KM on Organisational Practice: Applying the MeCTIP Model to UK Organizations': Electronic Journal of Knowledge Management,8(1):103-118.

Nagle, C. 1999. Research opportunities in knowledge management. Presented at theMid-Year Meeting of theAuditing Section of theAmerican Accounting Association (January 14).

Nidumolu, S., Subramani, M., \& Aldrich, A. (2001). Situated Learning and Situated 
INTERNATIONAL JOURNAL OF ACADEMIC RESEARCH IN BUSINESS AND SOCIAL SCIENCES Vol. 8, No. 9, Sept. 2018, E-ISSN: 2222-6990 (C) 2018 HRMARS

Knowledge Web: Exploring the Ground Beneath Knowledge Management. Journal of Management Information Systems, 18(1), 115-150.

Newman, B. (1991). An open discussion of knowledge management. In The Knowledge Management Forum archives

Nonaka, I. and Takeuchi, H. (1995), The Knowledge-Creating Company. How Japanese Companies Create The Dynamics of Innovation, Oxford University Press, Oxford.

Norzanah, M.N., Laily, M., Puteri, N.M. \& Mohd, R.H. (2006). Knowledge Worker and Knowledge Management: Some Descriptive Evidences on the MSC Status Companies in Malaysia. Proceedings of Knowledge Management Conference \& Exhibition - KMICE2006, 440-448. Universiti Utara Malaysia.

Obeidat, B. Y., Masa'deh, R. \& Abdallah, A. B. (2014). The Relationships among Human Resource Management Practices,Organizational Commitment, and Knowledge Management Processes: A Structural Equation Modeling Approach. International Journal of Business and Management, 9(3).

Okunoye, A. (2002). "Towards a Framework for Sustainable Knowledge Management in Organisations in Developing Countries," paper presented at the IFIP World Computer Congress Canada (WCC2002), Montreal, Canada.

Ortega-Parra, A., \& Sastre-Castillo, M. A. (2013). Impact of perceived corporate culture on organizational commitment. Management Decision, 51(5), 1071-1083. http://dx.doi.org/10.1108/MD-08-2012-0599

Othman, A. E. A. (2009). Strategic integration of human resource management practices: Perspectives of two major Japanese electrical and electronics companies in Malaysia. Cross Cultural Management: An International Journal, 16(2), 197-214. http://dx.doi.org/10.1108/13527600910953937

Porter, M., Millar, V., 1985. How information gives you competitive advantage. Harvard Business Review 63 (4), 149-160

Pruzinsky, M. \& Milhalcova,B. (2017).Employee Satisfaction and Knowledge Management. $12^{\text {th }}$ IWKM.Trencin,Slovakia.

Rahman, B. A. (2004). “Knowledge management initiatives: Exploratory Study in Malaysia," Journal of American Academy of Business, (4), 330-336.

Riveros, A. M., \& Tsai, T. S. T. (2011). Career commitment and organizational commitment in for-profit and non-profit sectors. International Journal of Emerging Science, 1(3), 324-340. 
INTERNATIONAL JOURNAL OF ACADEMIC RESEARCH IN BUSINESS AND SOCIAL SCIENCES Vol. 8, No. 9, Sept. 2018, E-ISSN: 2222-6990 @ 2018 HRMARS

Robbins, M.J., Peterson, M., Tedrick, T. and Carpenter, J.R. (2003), "Job satisfaction on NCAA division III athletic directions: impact of job design and time on task", International Sports Journal, 7(2),46-57.

Saed, M, S. (2016). The Impact of Job Satisfaction and Knowledge Sharing on Employee Performance. Journal of Resources Development and Management, 21.

Savaneviciene, A., \& Stankeviciute, Z. (2011). Human resource management practices linkages with organizational commitment and job satisfaction. Economics and Management, 16, 921-928.

Scharmer, C.O. (2001), "Self-transcending knowledge: sensing and organizing around emerging opportunities", Journal of Knowledge Management,5(2),137-151.

Shaikh, M.A., Bhutto, N.A. and Maitlo, Q. (2012), "Facets of job satisfaction and its association with performance", International Journal of Business and Social Science,3( 7) , 322-327.

Singh,A.K.\& Sharma,V. (2011). Knowledge Management antecedents and its impact on employee satisfaction: A study on Indian telecommunications industries. The learning organization, 18(2),115-130.

Smith, P.C., Kendall, L.M. and Hulin, C.L. (1969), The Measurement of Satisfaction in Work and Retirement, Rand McNally, Chicago, IL

Spiegler, I. “Knowledge Management: A New Idea or a Recycled Concept?" Communications of the Association for Information Systems (3:1), June 2000,

Spector, P. (1997), Job Satisfaction: Application, Assessment, Causes, and Consequences, Sage Publications, London.

Spector, P. (1994), Job Satisfaction Survey, University of South Florida, Tampa, FL.

Saeed,M.S (2016). The impact of job satisfaction and knowledge sharing on employee performance, An International Peer-review Journal,21.

Syed-Ikhsan, S. O. S. \& Rowland, F. (2004). "Benchmarking knowledge management in a public organization in Malaysia," Benchmarking: An International Journal, (11:3), pp. 238-266.

Teece, D.J., Pisano, G. and Schuen, A. (1997), “Dynamic capabilities and strategic management", Strategic Management Journal, Vol. 18, pp. 509-533.

Tiwana, A. (2003). The knowledge management toolkit: Orchestrating IT, Strategy and Knowledge Platforms. Upper Saddle River, NJ: Prentice Hall.

Tiwari, P., \& Saxena, K. (2012). Human resource management practices: A comprehensive 
INTERNATIONAL JOURNAL OF ACADEMIC RESEARCH IN BUSINESS AND SOCIAL SCIENCES Vol. 8, No. 9, Sept. 2018, E-ISSN: 2222-6990 (C) 2018 HRMARS

review. Pakistan Business Review, 669-705.

Toh, H. H., Jantan, M., \& Ramayah, T. (2003). "Knowledge management: An exploratory study on Malaysian organization," The International Journal of Knowledge, Culture and Change Management, (3), pp. 995-1014.

Trivellas., P. Akrivouli., Z. Tsifora., E. \& Tsoutsa., P. (2015). The impact of knowledge sharing culture on job satisfaction in accounting firms. The mediating effect of general competencies. Procedia Economics and Finance. 19. 238 - 247

Tsai, W. (2001) Knowledge transfer in intra-organizational networks: Effects of network position and absorptive capacity on business unit innovation and performance. Academy of Management Journal, 44(5), 996-1004.

Vanhala, S., \& Stavrou, E. (2013). Human resource management practices and the HRMperformance link in public and private sector organizations in three Western societal clusters. Baltic Journal of Management, 8(4), 416-437. http://dx.doi.org/10.1108/BJM-122012-011

Von Krogh, G. (1998), "Care in knowledge creation”, California Management Review, 40 (3),133-154.

Vroom, V. (1964). Work and Motivation. Jhon Wiley and Sons, 91.

Wiig, K. M., \& Jooste, A. (2003). Exploiting knowledge for productivity gains Handbook on knowledge management (289-308): Springer.

Wijetunge, P. (2002). Adoption of knowledge management by the Sri Lankan University librarians in the light of the National Policy on University Education. International Journal of Educational Development, 22, 85-94

Woods, P. (2005). Knowledge Management in Malaysia - The Facts. Retrieved November, 2009 from http://www.kmtalk.net/

Wenger, E., R. A. McDermott, et al. (2002). Cultivating communities of practice: a guide to managing knowledge. Boston, Mass., Harvard Business School Press.

Yew, L. T. (2013, July 8). The influence of Human Resources Management (HRM) practices on organizational commitment and turnover intention of academics in Malaysia: The organizational support perspective. Paper presented at the International Conference of Business and Information, Bali, Indonesia

Zack, M. H. (1999). Knowledge and Strategy. Boston: Butterworth-Heinemann

Zaim, H., Tatoglu, E., \& Zaim, S. (2007). “Performance of knowledge management practices: a 
INTERNATIONAL JOURNAL OF ACADEMIC RESEARCH IN BUSINESS AND SOCIAL SCIENCES

Vol. 8, No. 9, Sept. 2018, E-ISSN: 2222-6990 @ 2018 HRMARS

causal analysis," Journal of Knowledge Management,11(6),54-67.

Zahra, S.A. and George, G. (2002), "Absorptive capacity: a review, reconceptualization, and extension", Academy of Management Review,27(2),185-203. 